\title{
Dressing your soul: The role of brand engagement in self-concept
}

\author{
Valentina Mazzoli ${ }^{* *}$, Diletta Acuti ${ }^{* * *}$, Raffaele Donvito ${ }^{* * *}$, \\ Eunju Ko ${ }^{* \star \star *}$
}

\begin{abstract}
The current study aims to contribute to the literature on brand engagement in self-concept (BESC). Supported by self-determination theory, a comprehensive model that explains the psychological drivers and consequences of BESC is tested. Based on a sample of 600 international highly engaged cosplayers, the results contribute to the literature on BESC by showing that extrinsic personal aspirations positively influence individuals' propensity to include brands in their definition of themselves. The findings show that higher levels of extrinsic personal aspirations lead to higher BESC manifestations that in turn lead to greater brand loyalty and brand advocacy. Furthermore, the findings indicate that personal aspirations have an indirect effect on brand loyalty and brand advocacy through BESC. The managerial implications for fashion brands are discussed.
\end{abstract}

\footnotetext{
* This paper was presented at the XIV SIM Annual Conference at Bergamo and it is one of the results coming from the international cooperation between the members of the Global Alliance of Marketing \& Management Associations (GAMMA) and the Italian Marketing Association (SIMktg). This cooperation has been facilitated by the Joint Symposium co-organized by the associations during the 2017 Global Fashion Management Congress at Vienna and the 2018 Global Marketing Congress at Tokyo.

${ }^{* *}$ Post-Doc Research Fellow, Department of Economics and Management, University of Florence. E-mail: valentina.mazzoli@unifi.it.

${ }^{* * *}$ Post-Doc Research Fellow, Department of Economics and Management, University of Florence.E-mail: diletta.acuti@unifi.it.

${ }^{* * * *}$ Associate Professor of Marketing, Department of Economics and Management, University of Florence. E-mail: raffaele.donvito@unifi.it.

${ }^{* * * * *}$ Full Professor of Marketing, Department of Clothing and Textiles, Yonsei University Seoul South Korea. E-mail: ejko@yonsei.ac.kr.
}

Mercati \& Competitività (ISSN 1826-7386, eISSN 1972-4861), 2019, 1

Copyright $\odot$ FrancoAngeli

This work is released under Creative Commons Attribution - Non-Commercial

- NoDerivatives License. For terms and conditions of usage

please see: http://creativecommons.org 
Valentina Mazzoli, Diletta Acuti, Raffaele Donvito, Eunju Ko

Keyword: brand engagement in self-concept, self-determination theory, brand advocacy, brand loyalty, cosplayer.

First submission: 12/02/2018, accepted: 10/11/2018

\section{Introduction}

The literature on consumer behaviour provides insights into the phenomenon of consumers expressing some aspects of themselves through products and brands (Holman, 1980; Hassenzahl, 2018).

In the consumption setting, the literature establishes the importance of cultivating specific self-presentations through personal adornment as a means of achieving a variety of identity goals (Thompson \& Haytko, 1997; Thomson, Whelan \& Johnson, 2012). When consumers engage in consumption, they can use the product to express who they want to be, communicating their expression of the perceived authentic self, and who they should be, adhering to appropriate socio-cultural conduct (Liu \& Hogg, 2018).

Thus, consumers tend to define themselves by engaging with brands in public or in private (Ferraro, Escalas \& Bettman, 2011). For this reason, the retail clothing industry designs and formulates a large-scale communication strategy using self-concept as the denominator for building corporate brands and attracting target customers. Consumers are also likely to use precious jewellery brands to enhance their self-image while treating the jewellery as a very special personal belonging (Jamal \& Goode, 2001). The literature refers to this phenomenon as the brand engagement in self-concept (BESC) construct. Because BESC potentially explains a great deal of consumer decision making, it is crucial for understanding why consumers select one brand among others (Flynn, Goldsmith \& Korzenny, 2011). Studies on BESC support the idea that consumers construe their self-concepts in terms of their favourite brands and that such construal can have important implications for marketers in terms of brand equity (Keller, 1993), attention to brands (Sprott, Czellar \& Spangenberg, 2009) and brand preference (Liu et al., 2018). Despite the importance of BESC, the theoretical understanding of the linkage between brands and specific aspects of self remains incomplete (Ewing \& Allen, 2017). For instance, studies on BESC focus on the relationship between BESC and consumer behaviour, such as brand loyalty (Sprott, Czellar \& Spangenberg, 2009), without considering antecedents, while other studies focus only on drivers (Razmus, Jaroszyńska \& Palęga, 2017). Consequently, a comprehensive model that considers the antecedents and consequences of BESC is still lacking.

Copyright $(\odot$ FrancoAngeli

This work is released under Creative Commons Attribution - Non-Commercial

- NoDerivatives License. For terms and conditions of usage

please see: http://creativecommons.org 
Clothes and fashion brands, even more than other material goods, are consumed not only for their functional benefits but also as symbols of identity (Cox \& Dittmar, 1995; Kim \& Kang, 2015). Some individuals identify clothing as a tactical tool for self-definition, thus exercising control over the way in which individuals present themselves to others (Peluchette, Karl \& Rust, 2006). A paper by Levy (1959) states that 'People buy things not only for what they can do, but for what they mean' (p. 118). Robertson (1970) asserts that products vary in the degree to which their social-symbolic meaning is important; he describes items of clothing as products that are recognized in our society as 'saying something' about a person (p. 3). Indeed, clothing is recognized as a medium of communication that expresses a range of social information (Rosenfeld \& Plax, 1977).

To gain a better understanding of this phenomenon, the present study adopts the self-determination theory to define the antecedents and the consequences of BESC. Scholars suggest that self-brand connections exist and can lead to favourable brand attitudes (Escalas \& Bettman, 2003). In particular, we would like to shed light on the relationship between engagement and brandrelated constructs such as brand advocacy and brand loyalty (Grappi \& Visentin, 2008; Dessart, Veloutsou \& Morgan-Thomas, 2015). These two constructs, as well as BESC, are relevant determinants of the consumer-brand relationship (Dwivedi, 2015; Hsiao, Shen \& Chao, 2015). While advocacy and loyalty are related to the linkage with a specific brand, BESC indicates how consumers vary in their general engagement with brands. Advocacy and loyalty can be affected by the tendency of consumers to create a deep relationship with their favourite brands and include them as part of their self-concept. Thus, the importance for companies of improving the commitment of consumers to re-buying or re-patronizing a preferred product and recommending the brand to others is well acknowledged. For this reason, it is relevant to study how brand loyalty and advocacy can be influenced by BESC and how managers can consequently develop their brand strategies.

With this aim, we propose a comprehensive model including the antecedents (as already investigated by Razmus, Jaroszyńska \& Palęga, 2017) and the consequences of BESC. Moreover, we test this model in a community of high-engagement manifestations: the cosplayer community. In general, the literature acknowledges that consumers choose brands with appealing personalities to enhance their selves (Torelli, Monga \& Kaikati, 2011) or their ideal selves (Belk, 1988). It also demonstrates that consumers appear to be especially driven by their ideal selves in public circumstances (Swaminathan, Stilley \& Ahluwalia, 2008). By using brands as subtle cues, consumers communicate idealized versions of their selves, even more so in aggregate

Copyright $(\odot$ FrancoAngeli

This work is released under Creative Commons Attribution - Non-Commercial

- NoDerivatives License. For terms and conditions of usage

please see: http://creativecommons.org 
than their actual selves (Hollenbeck \& Kaikati, 2012). The ideal self represents either an expansion of the self or a contraction of the self (Hollenbeck $\&$ Kaikati, 2012). Indeed, brands are imbued with symbolic meanings, and, through these meanings, they can serve as a means for consumers to express aspects of their ideal self (Belk, 1988). The community of cosplayers, a form of pop culture craft consumption and masquerade (Seregina \& Weijo, 2016), can be interpreted as an extreme case of dressing to express one's ideal self. This specific case can be useful in analysing the propensity to dress to transmit self-identity, representing a new turn in the conception of self (Geczy, 2016). Indeed, the wearing of a costume symbolically transforms the identity of players, enabling them to represent their ordinary self in a new guise through role play (Peirson-Smith, 2013).

This research offers an advancement of the literature by explaining the antecedents of brand engagement in self-concept and testing how this construct can affect brand advocacy and loyalty. By testing the model in the cosplayer community, the present study sheds light on the importance of BESC for the fashion industry, clarifying how individuals use clothes to convey to others a specific image of the self. In the first paragraph of the paper, we introduce the concept of BESC through the self-determination theory and we explain the antecedents and consequences of BESC, which we will test in the empirical study. Therefore, we introduce the context of the research fashion - showing how fashion products and brands assume a crucial role regarding the self-concept expression of consumers. In the second paragraph, we describe the methodology adopted to investigate the phenomenon and to test the model. The results are then discussed, and finally we conclude by highlighting the contribution of the paper to theory and practice and suggest some future directions for research.

\section{Theoretical background and hypothesis development}

\subsection{Self-determination theory and brand engagement in self-concept}

As the previous literature shows, the consumer-brand relationship is influenced by the link between the brand and the self (Belk, 1988; Aaker, Fournier \& Brasel, 2004; Aggarwal, 2004), leading to self-connection or other related terms such as self-congruence or self-presentation. Recent research on the consumer-brand relationship focuses on the differences between consumers (Fetscherin \& Heinrich, 2015) with respect to their engagement with brands (Sprott, Czellar \& Spangenberg, 2009; Van Doorn et al., 2010; Dessart, Veloutsou \& Morgan-Thomas, 2015; Leckie, Nyadzayo \& Johnson, 2016).

Copyright $(\odot$ FrancoAngeli

This work is released under Creative Commons Attribution - Non-Commercial - NoDerivatives License. For terms and conditions of usage please see: http://creativecommons.org 
Research published over the years conceptualizes the construct of engagement in various ways, focusing on several dimensions, antecedents, outcomes and foci of interest. Traditionally, engagement is studied with reference to the relationship between the brand and the consumer. One of the first contributions defines engagement as the 'customer behavioural manifestations toward the brand or the firm, beyond purchase' (Van Doorn et al., 2010, p. 253). Similarly, Kumar et al. (2010) refer to engagement in terms of customers' behaviours 'that are beyond direct transactions' (p. 297) in relation to customers' behavioural manifestations toward the brand, as research considers recommendations, referrals, word of mouth and blogging (i.e. Trusov, Bucklin \& Pauwels, 2009; Kumar et al., 2010; Schmitt, Skiera \& Van den Bulte, 2011; Verlegh et al., 2013). In more recent work, the construct is further developed by focusing not only on the behavioural dimension but also on the cognitive and emotional ones (Hollebeek, 2011; Harmeling et al., 2017). Cognitive activity refers to the level of concentration on and/or engrossment in the brand, while emotional activity refers to the level of brandrelated inspiration and/or pride. Along with this perspective, Brodie et al. (2011) define engagement as the 'psychological state that occurs by virtue of interactive, co-creative customer experiences with a focal/object' (p. 9).

Among the other studies examining customer brand engagement, the study by Sprott et al. (2009) introduces the concept of BESC, which can be considered as 'the individual difference representing consumers' propensity to include important brands as part of how they view themselves' (p. 92). Drawing on a theory developed by Markus (1983), the same authors contend that self-concept is the set of self-schemas that originate from stable knowledge structures about the self and that are used to interpret incoming self-related information to help people to make sense of themselves in their environment. Consequently, people's varying tendency to possess self-schemas leads to differential attitudes and behaviour towards those objects that are relevant to those schemas (e.g. brand, community and characters). Therefore, the underlying assumption of the BESC construct stems from the varying tendency of consumers to possess brand-related schemas (Sprott, Czellar $\&$ Spangenberg, 2009). For this reason, people develop different brand-related cognitions, perceptions and behaviours and vary in their tendency to engage in identity building and expression through brand communities (Muniz \& O'Guinn, 2001). In summary, Sprott, Czellar and Spangenberg (2009) posit the following logical path: stable knowledge about the self $\rightarrow$ self-schemas for interpreting the environment $\rightarrow$ self-concept $\rightarrow$ BESC (engagement with brands to build and maintain the self-concept). Thus, different schemas $\rightarrow$ different BESC.

Copyright $(\odot$ FrancoAngeli This work is released under Creative Commons Attribution - Non-Commercial - NoDerivatives License. For terms and conditions of usage please see: http://creativecommons.org 
In this vein, the self-determination theory - a theory of human motivation concerned with the development and functioning of personality within social contexts - explains how people are pushed into action by a variety of factors (Ryan \& Deci, 2000). This theory asserts that people are active organisms with a natural tendency towards psychological growth and development (Sheldon et al., 2001). From this perspective, individuals' behaviour is self-determined and people act to achieve their most salient goals.

The self-determination theory (Ryan \& Deci, 2000) can be useful in the case of cosplayers, because they manifest their brand engagement in self-concept by dressing up as characters who reflect their personal aspirations (Winge, 2006; Kane, 2017).

The factors that push people into actions can be associated with two types of goals: intrinsic and extrinsic (Razmus, Jaroszyńska \& Palęga, 2017). The number of goals in this theory has evolved from four (Kasser \& Ryan, 1993) to seven (Kasser \& Ryan, 1996). In this research, we adopt Razmus, Jaroszyńska and Palęga's (2017) perspective, in which six goals are considered. Namely, the intrinsic goals are represented by (1) self-acceptance (achieve psychological growth, autonomy and self-regard); (2) affiliation (have satisfying relationships with family and friends); and (3) community feeling (improve the world through activism). The extrinsic goals consist of: (4) financial success (be wealthy and materially successful); (5) social recognition (be famous, well known and admired); and (6) appealing appearance (look attractive in terms of body, clothing and fashion).

Intrinsic goals are internally orientated and are inherently valuable or satisfying to the individual rather than being dependent on the contingent evaluation of others (Kasser \& Ryan, 1996; Otero-López \& Villardefrancos, 2015). Recent literature suggests that personal intrinsic aspirations are not positively associated with entering into relationships with brands, contrary to the previous notion in theoretical analyses (Razmus, Jaroszyńska \& Palęga, 2017). For example, studies demonstrate that intrinsic aspirations are negatively associated with the consumption of luxury goods (Truong, 2010; Truong, McColl \& Kitchen, 2010). Indeed, a core feeling of intrinsic aspirations is autonomy: strong links between intrinsic motivations and satisfaction of the needs for autonomy and competence are clearly demonstrated (Ryan \& Deci, 2000; Kim, Kasser \& Lee, 2003). The engagement of a brand in selfconcept to create and show a new identity reveals a lack of autonomy of the individual. In the context of cosplayers, this phenomenon is reflected in the use that individuals make of characters. The lower the level of intrinsic aspirations, the more the cosplayer needs the character to express and communicate the ideal self. 
This enables us to hypothesize that intrinsic aspirations negatively affect BESC. Consequently, the following hypotheses is formulated:

H1: Intrinsic aspirations negatively influence BESC. Self-acceptance (H1a), affiliation (H1b) and community feeling (H1c) are negatively and directly related to $B E S C$.

Individuals who pursue extrinsic goals tend to be concerned about how they are perceived by others and are motivated by a desire to earn praise and rewards (Truong, 2010). What really matters in this kind of motivation is the social aspect: a person may engage in actions to increase his or her value in other people's eyes. Therefore, as a considerable number of researchers state, consumers use brands to send certain signals to society (Berger \& Heath, 2007; Han, Nunes \& Drèze, 2010). This is specifically applicable to fashion brands, which for consumers become the means to be seen by others in specific ways (Kim \& Kang, 2015; Hassenzahl, 2018). Therefore, people who want to be considered as successful, socially recognized and attractive are more likely to develop a strong relationship with brands. From this perspective, we hypothesize as follows:

H2: Extrinsic aspirations positively influence BESC. Financial success (H2a), social recognition (H2b) and an appealing appearance $(\mathrm{H} 2 \mathrm{c})$ are positively and directly related to BESC.

The relationship between personal aspirations and BESC leads to brand advocacy and brand loyalty. Indeed, the literature suggests that BESC is relevant because it affects brand-related consumers' attitude and behaviour meaningfully (Sprott, Czellar \& Spangenberg, 2009). Brand advocacy consists of the promotion of a specific object embedded in the self (e.g. the brand or the character). According to Stokburger-Sauer, Ratneshwar and Sen (2012), such promotion, or advocacy, can take place both socially and physically. Socially, advocacy includes recommending the brand to others or defending the brand when it is attacked by others. Physically, advocacy may involve buying and using brand merchandise that displays concrete references to the brand, for instance by wearing a highly visible brand logo. HighBESC consumers are likely to integrate brands towards which they hold favourable attitudes into their self-concept. For these consumers, featuring a visible name or logo on products from a favourite brand is more likely to serve as an expression of the personal characteristics that they want to show to others. From this perspective, the higher the tendency of people to engage 
brands in the self-concept, the more they are willing to show, promote and defend the brand. With this premise, we propose the following hypothesis:

\section{H3: BESC positively influences brand advocacy.}

Brand loyalty is defined as 'a deeply held commitment to re-buy or repatronize a preferred product/service consistently in the future, thereby causing repetitive same-brand or same brand-set purchasing, despite situational influences and marketing efforts having the potential to cause switching behaviours' (Oliver, 1999, p. 3). Consumers develop brand loyalty by creating a positive output of brand equity, which positively engenders a preference for a certain brand over others (Vogel, Evanschitzky \& Ramaseshan, 2008; Zhang, van Doorn \& Leeflang, 2014).

The literature suggests that the close relationship of a brand with its consumers tends to reflect the level of positive affect generated by that brand; this strong and positive affective response is associated with high levels of brand loyalty (Chaudhuri \& Holbrook, 2001). BESC, representing consumers' propensity to include important brands as part of how they view themselves, is by definition a form of closeness to the brand. In this view, we expect a higher level of BESC to correspond to a higher level of loyalty. Formally, the following hypothesis is stated:

H4: BESC positively influences brand loyalty.

The hypotheses are summarized in the model shown in Figure 1.

Figure 1 - Theoretical model: antecedents and consequences of BESC

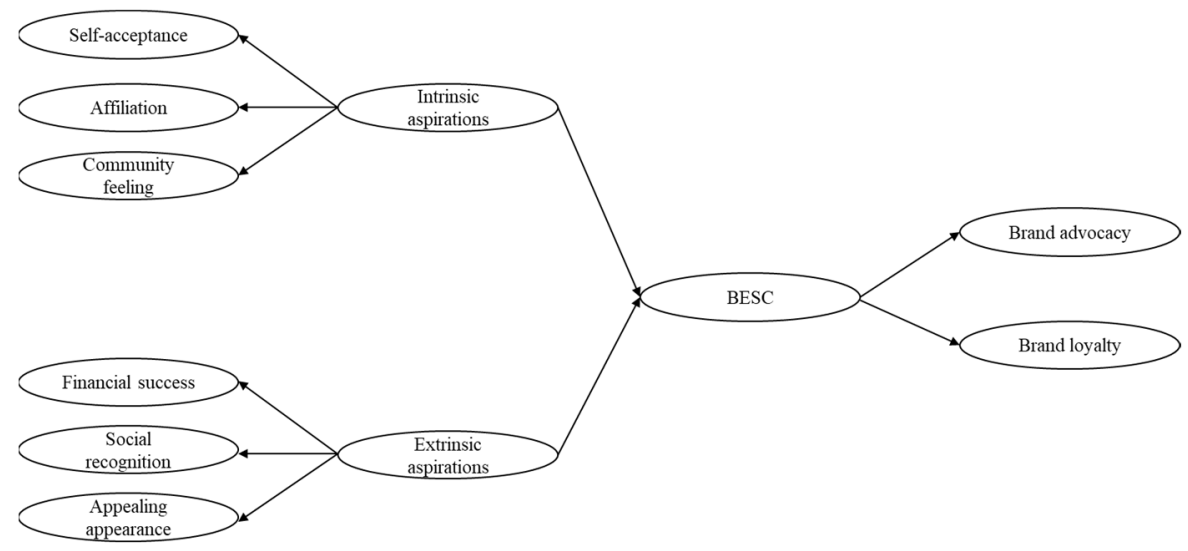




\subsection{Cosplayers, fashion and the self}

To test our hypotheses, we developed an empirical study in the context of cosplayers, a community with high-engagement manifestations that represents an extreme case of dressing to express oneself. The fashion industry offers products that can be used by consumers as tools of self-presentation, whereby an individual can create, maintain and modify the image to align with perceived social norms (McNeill, 2018). In this context, products and brands assume a crucial role for the self-concept that represents the primary determinant of people's self-presentation and the specific aspects of the self that individuals wish to control and portray. As an important aspect of nonverbal behaviour, clothing serves a wide variety of communicative functions. Veblen (1899) emphasizes that clothing consumption is far more than the physical need to protect the body, underlining the symbolic value of fashion in society. One relevant function of clothing is the interaction with other people. According to Bovone (2006), since individuals can have limited access to another person's identity through appearance, the body is the first element for discerning a person's character or personality. Another important role of clothing is the desire to differentiate oneself from others and furthermore from what others would normally expect. In this sense, clothing represents a tool for controlling the images that others have of us (Bruner, 1963). Clothing has another function; it can indicate the wearer's group membership or position within a group. Accordingly, fashion, adding aesthetic touches, is mostly a means of adhering to a specific social order (Hendricks, Kelley \& Eicher, 1968). Aiken (1963) tries to link clothing style with social position and personality. He finds that decoration in dress correlates positively with such traits as conformity, sociability and non-intellectualism. Therefore, the literature recognizes clothing as an instrument of communication that expresses a range of social information (McCracken \& Roth, 1989; Niinimäki, 2010). Considering all these functions of clothing, this research focuses on the link between people and the self.

An extreme case in which the communicative role of dressing clearly emerges is the phenomenon of cosplayers. The term cosplay is a linguistic mash-up that derives from the combination of the English words 'costume' and 'play' (Ito \& Crutcher, 2014) and refers to the practice of dressing up as characters from various fictional media (movies, series, videogames, anime and comics) during events, usually when attending various fan or industry conventions (Winge, 2006). The costume building draws inspiration mostly from 'geek culture' - that is, the increasingly popular consumption field of superheroes and fantasy - and is primarily (though not entirely) related to TV, comic book and video game franchises (Seregina \& Weijo, 2016).

Copyright $(\odot$ FrancoAngeli

This work is released under Creative Commons Attribution - Non-Commercial

- NoDerivatives License. For terms and conditions of usage

please see: http://creativecommons.org 
The practice of cosplay spans a vast geographical area, as many large national and international fan conventions and events demonstrate, such as Comic-Con International, Worldcon, World Cosplay Summit, Katsu Con, EOY Cosplay Festival and Lucca Comics.

Cosplay dress may be the most important tool that cosplayers have to communicate their chosen character and character traits non-verbally. The purposes of cosplaying can vary but include expressing adoration of the character, enjoying attention or approval from audiences/peers and experiencing the creative process of the costume construction (Rosenberg \& Letamendi, 2013). According to some authors, cosplayers annihilate their self-concept and achieve the death of the 'original self' (Geczy, 2016). According to other authors (Peirson-Smith, 2013), cosplayers do not completely destroy their original self but emphasize the characteristics of the original self and/or the characteristics of the character by coming closer to the ideal self. Adhering to the second branch of the literature, we underline how cosplay dress allows cosplayers to move from their actual identity to their chosen cosplay character and sometimes back again (Winge, 2006). According to Evans (2006), cosplayers escape from the regular communicative acts of their normal selves by expressing a fantasy self in public through the performative component of self-identification. However, in cosplay, the image and identity of an individual are never stagnant. It is possible that many cosplayers move between different characters according to their changing interests and passions. Individuals tend to wear different masks to construct, transform or reshape their temporary identity over the course of self-formation and transformation (Rahman, Wing-Sun \& Cheung, 2012). This phenomenon illustrates how clothes, even more than other material goods, are consumed not only for their functional benefits but also as symbols of identity (Cox \& Dittmar, 1995). Rosenberg and Letamendi (2013) suggest investigating this community and the relationship with the self. They state that similarity between one person and another often leads to increased liking, which could be true in the case of cosplayers and the characters that they portray. Some similarity between the cosplayer and the character increases identification, which in turn increases liking and a desire to be - albeit it temporarily - that character.

Therefore, we turn to the literature on the consumer-brand relationship. Indeed, from this point of view, comics represent a limit case, in which the main character of stories is immediately overlapped with the comic brand and conveys its desired identity and personality. In other cases, branding strategies may consider the opportunity to create an ad hoc character for communication needs. Characters may benefit the associated brands by establishing a strong identity and favourable associations (Dotz, Morton \& Lund, 
1996). Three broad typologies of characters exist: brand characters in animation and comics (e.g. Spider Man), brand characters with an identity (e.g. Michelin Man) and brand characters in pure design (e.g. Diddle). The case of cosplayers is embedded in the brand character in animation and comic typology. Brand characters in animation and comics offer a rich storyline and typically include other supporting characters as background. The storyline and visual animation impart personalities to the characters and relate to consumers' fantasies (Hosany et al., 2013). Consequently, a strong relationship is generated between brand, character and consumer.

\section{Methodology}

\subsection{Procedures and measures}

To test the theoretical model advanced in the previous section, we ran a structural equation modelling (SEM) with IBM AMOS Version 23. We developed a questionnaire on Qualtrics and submitted it by email to $600 \mathrm{mem}-$ bers of 2 different cosplayer communities on Facebook. We decided to collect responses from online cosplayer communities to target the questionnaire to cosplayers and reach an appropriate number of valid respondents. Each respondent received an email with a brief explanation of the survey and the link to complete it on Qualtrics. A filter question was asked first: 'Can you define yourself as a cosplayer?' People answering 'no' to this question were discarded. A second filter question tested the active role as a cosplayer of the individual. Accordingly, we asked the respondents whether they used to or usually dress up as famous characters, providing examples of the characters in whom we were interested (i.e. characters from various fictional media, such as movies, series, videogames, anime and comics). Again, for this question, people answering 'no' were discarded from the sample. The questionnaire was administered in English for the international community of cosplayers (actually formed by 37,450 members) and in Italian for the Italian community (actually consisting of 24,202 members). The Italian questionnaire was professionally translated from English into Italian and back from Italian into English to limit translation biases. The survey included 46 items (see Appendix - Table 2) employing a Likert scale from 1 to 7 (Likert, 1932). The items were randomized to improve the quality of the responses. Personal aspirations were measured using Razmus, Jaroszyńska and Palęga's (2017) description of 6 aspirations, based on the Kasser and Ryan (1996) model. We used 18 items related to intrinsic (self-acceptance, affiliation and community

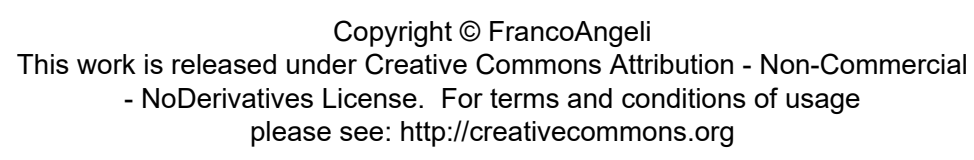


feeling) and extrinsic (financial success, social recognition and appealing appearance) aspirations basing on the Truong (2010) and Sheldon et al. (2001) scale. Following Sprott, Czellar and Spangenberg (2009), BESC was examined through 8 items. We measured brand advocacy using Kemp and Bui's (2011) 3-item scale adapted from Kim, Han and Park (2001), and we measured brand loyalty using Stokburger-Sauer, Ratneswar and Sen's (2012) 3item scale.

\subsection{The sample}

Of the 600 cosplayers approached, 416 responded to the questionnaire. More than half of the sample was female (63.3\%). The majority of the respondents were aged 21 to $25(33.3 \%)$. Around $20 \%$ were between 16 and 20 years old; $20.5 \%$ were 26 to $30 ; 5.8 \%$ were 36 to 40 ; and $8.3 \%$ were over 40. The composition of our sample reflects the overall composition of the cosplayer population. Indeed, statistics (ATA Blog, 2018) reveal that the majority of cosplayers are female (about 64\%) and aged between 23 and 39 years (about 60\%). In addition, we asked cosplayers whether they used to dress up as the same character or whether they have changed who they dress up as: $35.1 \%$ declared that they had changed their costume, while $64.9 \%$ had maintained the same one.

\section{Results and discussion}

\subsection{Validity and reliability tests}

The measures' reliability was first assessed through the measurement of Cronbach's alphas. All the constructs show Cronbach's alphas greater than .70 (all the Cronbach's alphas are reported in Table 2).

Confirmatory factor analysis was performed to test the measurement model with latent variables. To be able to make decisions regarding reliable constructs, the following features of the solution were investigated: unidimensionality, convergent validity, reliability and discriminant validity (Janssens et al., 2008). Unidimensionality and convergent validity are satisfied, since all the variables' measures have a high loading $(>.50)$ on the latent variables and are significant (critical ratio $=$ C.R. $=$ t-value $>1.96$; Table $1)$. 
Dressing your soul: The role of brand engagement in self-concept

Table 1 - Regression weights (group number 1 - default model)

\begin{tabular}{|c|c|c|c|c|c|}
\hline & & $\begin{array}{l}\text { Estimate } \\
\text { (unstandardized) }\end{array}$ & $\begin{array}{l}\text { Estimate } \\
\text { (standardized) }\end{array}$ & S.E. & C.R. \\
\hline Com_Feel_Tot & <--- Intrinsic_asp & 1.000 & 0.619 & & \\
\hline Affiliation_Tot & <--- Intrinsic_asp & 0.897 & 0.634 & 0.150 & 5.979 \\
\hline Self_Acc_Tot & <--- Intrinsic_asp & 0.687 & 0.512 & 0.111 & 6.167 \\
\hline Financ_Succ_Tot & <--- Extrinsic_asp & 1.000 & 0.619 & & \\
\hline Appeal_Tot & <--- Extrinsic_asp & 1.415 & 0.865 & 0.130 & 10.849 \\
\hline Soc_Rec_Tot & $<---$ Extrinsic_asp & 1.031 & 0.728 & 0.092 & 11.191 \\
\hline BESC_1 & $<---$ BESC & 1.000 & 0.833 & & \\
\hline BESC_2 & $<---$ BESC & 1.116 & 0.871 & 0.049 & 22.834 \\
\hline BESC_3 & $<---$ BESC & 1.200 & 0.907 & 0.049 & 24.485 \\
\hline BESC_4 & $<---$ BESC & 1.104 & 0.823 & 0.053 & 20.773 \\
\hline BESC_5 & $<---\quad B E S C$ & 1.197 & 0.895 & 0.050 & 23.931 \\
\hline BESC_6 & $<---$ BESC & 1.173 & 0.885 & 0.050 & 23.458 \\
\hline BESC_7 & $<---$ BESC & 1.090 & 0.853 & 0.049 & 22.030 \\
\hline BESC_8 & $<---$ BESC & 1.018 & 0.8 & 0.051 & 19.884 \\
\hline ADVOC_1 & <--- Advocacy & 1.000 & 0.772 & & \\
\hline ADVOC_2 & <--- Advocacy & 1.140 & 0.837 & 0.069 & 16.472 \\
\hline ADVOC_3 & <--- Advocacy & 1.026 & 0.753 & 0.068 & 15.001 \\
\hline LOYALTY_1 & <--- Loyalty & 1.000 & 0.733 & & \\
\hline LOYALTY_2 & $<---$ Loyalty & 1.262 & 0.861 & 0.075 & 16.798 \\
\hline LOYALTY_3 & <--- Loyalty & 1.333 & 0.877 & 0.078 & 17.008 \\
\hline
\end{tabular}

The overall fit determines the degree to which the covariance matrix generated by the model corresponds to the actual (observed) covariance matrix (Janssens et al., 2008). In our case, the chi-square value (discrepancy) is 536.656 with a p-value of $<.001$; therefore, the null hypothesis is rejected, indicating a bad fit of the overall measurement model. However, examining the chi-square value alone often leads to the model having to be rejected (particularly with larger samples). Accordingly, the overall fit is poor considering the CMIN $/ d f$, which is 3.35 , and the goodness of fit index (GFI), which is equal to .89 . However, the model is acceptable according to the adjusted goodness of fit index (AGFI), which is greater than .80 (equal to .85). In addition, the Tucker-Lewis index (TLI) and the comparative fit index (CFI) are both greater than the 90 cut-off (Byrne, 2016), respectively equalling .92 and .93 , which indicate an acceptable model. The RMSEA is .08 
here. According to Browne and Cudeck (1993), values up to .08 indicate an acceptable fit.

Reliability was assessed through the variance extracted criterion. Each construct has a value greater than .50 , and the variance extracted for each latent variable is shown in Table 2.

Finally, discriminant validity was assessed through the mutual variances between the latent variables. As shown in Table 3, none of the variances that is shared by two constructs is higher than the average variance extracted of these constructs. This finding indicates discriminant validity for the five constructs that were formed.

In conclusion, the measurement model proves to be unidimensional and reliable and indicates convergent and discriminant validity.

Table 2 - CFA results

\begin{tabular}{|c|c|c|c|c|}
\hline Construct & Items & AVE & CR & C. $\alpha$ \\
\hline \multirow[t]{3}{*}{ Intrinsic aspiration } & Com_Feel & 0.615 & 0.349 & 0.803 \\
\hline & Affiliation & & & \\
\hline & Self_Acc & & & \\
\hline \multirow[t]{3}{*}{ Extrinsic aspiration } & Financ_Succ & 0.785 & 0.554 & 0.876 \\
\hline & Appeal & & & \\
\hline & Soc_Rec & & & \\
\hline \multirow[t]{8}{*}{ BESC } & BESC_1 & 0.957 & 0.738 & 0.957 \\
\hline & BESC_2 & & & \\
\hline & BESC_3 & & & \\
\hline & BESC_4 & & & \\
\hline & BESC_5 & & & \\
\hline & BESC_6 & & & \\
\hline & BESC_7 & & & \\
\hline & BESC_8 & & & \\
\hline \multirow[t]{3}{*}{ Advocacy } & ADVOC_1 & 0.831 & 0.621 & 0.831 \\
\hline & ADVOC_2 & & & \\
\hline & ADVOC_3 & & & \\
\hline \multirow[t]{3}{*}{ Loyalty } & LOYALTY_1 & 0.865 & 0.683 & 0.858 \\
\hline & LOYALTY_2 & & & \\
\hline & LOYALTY_3 & & & \\
\hline
\end{tabular}

Notes: Model fit: $\mathrm{X}^{2}=536.656, \mathrm{df}=160, \mathrm{NFI}=0.907, \mathrm{IFI}=0.933, \mathrm{CFI}=0.932, \mathrm{GFI}$ $=0.885$, RMSEA $=0.075$.

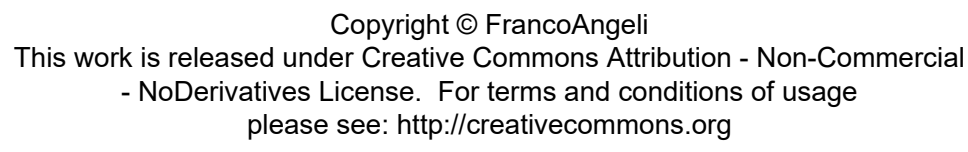


Table 3 - Discriminant validity

\begin{tabular}{llllll}
\hline & Intrinsic aspiration & Extrinsic aspiration & BESC & Advocacy & Loyalty \\
\hline Intrinsic aspiration & $\mathbf{0 . 6 1 5}$ & & & & \\
Extrinsic aspiration & 0.007 & $\mathbf{0 . 7 8 5}$ & & & \\
BESC & 0.003 & 0.011 & $\mathbf{0 . 9 5 7}$ & & \\
Advocacy & 0.004 & 0.041 & 0.462 & $\mathbf{0 . 8 3 1}$ & \\
Loyalty & 0.004 & 0.052 & 0.404 & 0.490 & $\mathbf{0 . 8 6 5}$ \\
\hline
\end{tabular}

\subsection{Hypotheses testing}

The hypotheses were tested using path analysis, which involves the estimation of structural relationships between latent variables. Although the model presents low scores for the GFI (.87) and AGFI (.84), it is acceptable due to the good scores of the TLI (.91), CFI (.92) and RMSEA (0.08). In Tables 4 and 5, the unstandardized and standardized regression coefficients are shown, respectively.

Extrinsic aspirations appear to have a significant influence, while intrinsic aspirations have no influence, on the degree of BESC. Thus, H1 is not confirmed, while $\mathrm{H} 2$ is supported. This suggests that intrinsic aspirations, such as self-acceptance, affiliation and community feeling, are not negatively associated with BESC, as suggested by Razmus, Jaroszyńska and Palęga (2017). However, the literature on intrinsic aspirations and brand identification is quite confused, since some studies show a positive relationship between intrinsic aspirations and brand identification (e.g. Stokburger-Sauer, Ratneshwar \& Sen, 2012), whilst other studies provide empirical evidence of a negative relationship between intrinsic aspirations and brand identification (e.g. Truong, 2010). Despite the dissonance among the results about the link between intrinsic aspirations and brand identification, the predominant materialistic component of BESC hardly justifies a positive association between intrinsic aspiration and BESC, as we showed in our analysis. This means that individuals are almost indifferent to treating their inclusion of characters in their self-concept as a substitute for relations with people. This study aligns with recent reports about the need to distinguish the nature of emotional attitudes towards brands from that of emotional attitudes towards people (Marketing Science Institute, 2016). The obtained result seems to limit the role of emotional motives in choosing cosplay characters, since they are not associated with BESC. However, emotional attitudes towards people

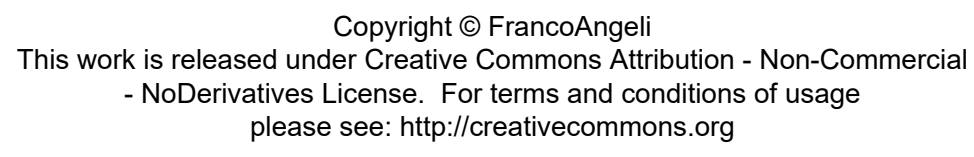


appear to play a significant role in the choice of the cosplay dress, since $\mathrm{H} 2$ demonstrates that extrinsic aspirations are significant in explaining consumer behaviours.

The tests of $\mathrm{H} 3$ and $\mathrm{H} 4$ are strongly significant and show that BESC positively influences respectively brand advocacy and brand loyalty. The evidence sheds light on the consequences of BESC. The analysis confirms that higher levels of extrinsic aspiration generate a higher BESC level, which consequently increases the willingness to spread positive word of mouth related to the brand/character (brand advocacy) and the willingness to repurchase items related to that character or to dress multiple times as that character (brand loyalty). Figure 2 summarizes the comprehensive analysis of the antecedents and consequences of BESC that we ran.

Figure 2 - SEM results of the model

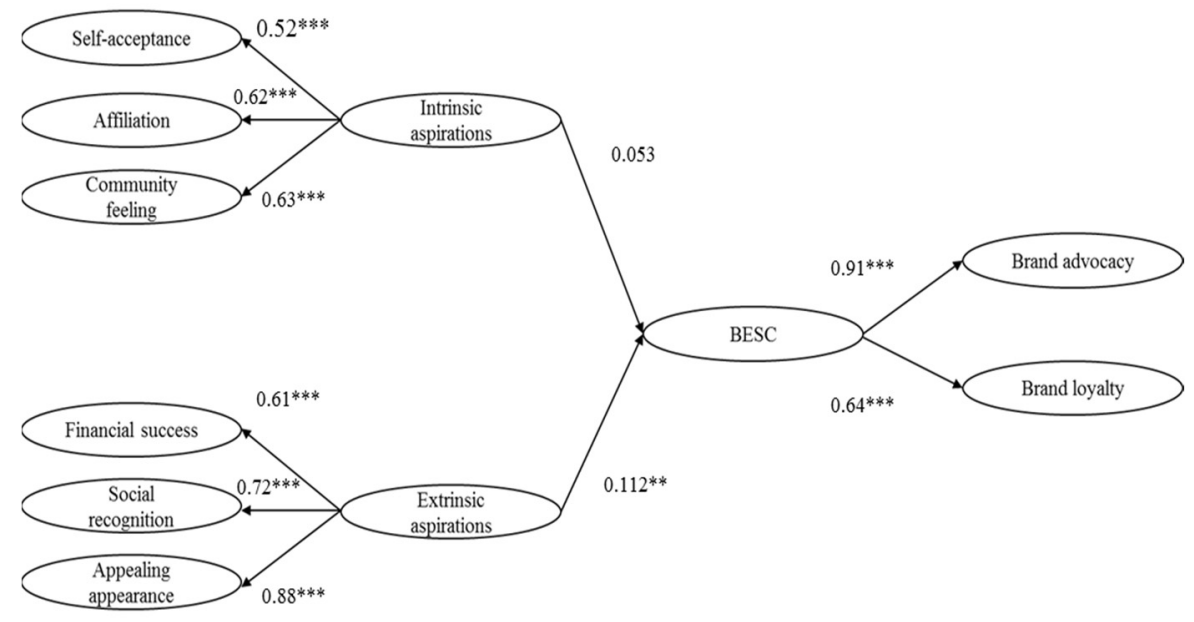


Dressing your soul: The role of brand engagement in self-concept

Table 4 - Regression weights (group number 1 - default model)

\begin{tabular}{|c|c|c|c|c|c|c|}
\hline & & & Estimate & S.E. & C.R. & $\mathbf{P}$ \\
\hline BESC & $<--$ & Extrinsic_asp & 0.183 & 0.09 & 2.026 & ** \\
\hline BESC & $<--$ & Intrinsic_asp & 0.112 & 0.134 & 0.842 & 0.4 \\
\hline Advocacy & $<--$ & BESC & 0.655 & 0.053 & 12.357 & *** \\
\hline Loyalty & $<--$ & BESC & 0.581 & 0.051 & 11.355 & *** \\
\hline Com_Feel_Tot & $<--$ & Intrinsic_asp & 1 & & & \\
\hline Affiliation_Tot & $<--$ & Intrinsic_asp & 0.873 & 0.146 & 5.968 & $* * *$ \\
\hline Self_Acc_Tot & $<--$ & Intrinsic_asp & 0.686 & 0.112 & 6.134 & *** \\
\hline Financ_Succ_Tot & $<--$ & Extrinsic_asp & 1 & & & \\
\hline Appeal_Tot & $<--$ & Extrinsic_asp & 1.454 & 0.138 & 10.502 & *** \\
\hline Soc_Rec_Tot & $<--$ & Extrinsic_asp & 1.03 & 0.093 & 11.097 & *** \\
\hline BESC_1 & $<--$ & BESC & 1 & & & \\
\hline BESC_2 & $<--$ & BESC & 1.113 & 0.049 & 22.831 & *** \\
\hline BESC_3 & $<--$ & BESC & 1.197 & 0.049 & 24.499 & *** \\
\hline BESC_4 & $<--$ & BESC & 1.104 & 0.053 & 20.846 & *** \\
\hline BESC_5 & $<--$ & BESC & 1.193 & 0.05 & 23.897 & *** \\
\hline BESC_6 & $<--$ & BESC & 1.17 & 0.05 & 23.481 & *** \\
\hline BESC_7 & $<--$ & BESC & 1.089 & 0.049 & 22.092 & *** \\
\hline BESC_8 & $<--$ & BESC & 1.018 & 0.051 & 19.932 & *** \\
\hline ADVOC_1 & $<--$ & Advocacy & 1 & & & \\
\hline ADVOC_2 & $<--$ & Advocacy & 1.146 & 0.072 & 15.985 & *** \\
\hline ADVOC_3 & $<--$ & Advocacy & 1.035 & 0.07 & 14.787 & *** \\
\hline LOYALTY_1 & $<--$ & Loyalty & 1 & & & \\
\hline LOYALTY_2 & $<--$ & Loyalty & 1.293 & 0.079 & 16.405 & *** \\
\hline LOYALTY_3 & $<--$ & Loyalty & 1.362 & 0.082 & 16.533 & *** \\
\hline
\end{tabular}


Valentina Mazzoli, Diletta Acuti, Raffaele Donvito, Eunju Ko

Table 5 - Standardized regression weights: (group number 1 - default model)

\begin{tabular}{|c|c|c|c|}
\hline & & & Estimate \\
\hline BESC & $<---$ & Extrinsic_asp & 0.112 \\
\hline BESC & $<---$ & Intrinsic_asp & 0.053 \\
\hline Advocacy & $<--$ & BESC & 0.691 \\
\hline Loyalty & $<--$ & BESC & 0.643 \\
\hline Com_Feel_Tot & $<---$ & Intrinsic_asp & 0.625 \\
\hline Affiliation_Tot & $<---$ & Intrinsic_asp & 0.623 \\
\hline Self_Acc_Tot & $<---$ & Intrinsic_asp & 0.517 \\
\hline Financ_Succ_Tot & $<--$ & Extrinsic_asp & 0.612 \\
\hline Appeal_Tot & $<--$ & Extrinsic_asp & 0.878 \\
\hline Soc_Rec_Tot & $<--$ & Extrinsic_asp & 0.719 \\
\hline BESC_1 & $<---$ & BESC & 0.834 \\
\hline BESC_2 & $<---$ & BESC & 0.870 \\
\hline BESC_3 & $<--$ & BESC & 0.906 \\
\hline BESC_4 & $<--$ & BESC & 0.824 \\
\hline BESC_5 & $<---$ & BESC & 0.893 \\
\hline BESC_6 & $<--$ & BESC & 0.884 \\
\hline BESC_7 & $<---$ & BESC & 0.854 \\
\hline BESC_8 & $<--$ & BESC & 0.801 \\
\hline ADVOC_1 & $<---$ & Advocacy & 0.768 \\
\hline ADVOC_2 & $<--$ & Advocacy & 0.838 \\
\hline ADVOC_3 & $<---$ & Advocacy & 0.756 \\
\hline LOYALTY_1 & $<---$ & Loyalty & 0.721 \\
\hline LOYALTY_2 & $<--$ & Loyalty & 0.867 \\
\hline LOYALTY_3 & $<--$ & Loyalty & 0.881 \\
\hline
\end{tabular}


Since the model can be read as implying that BESC mediates the relationship of motivations with brand loyalty and advocacy, we provide mediation analysis results. We performed the mediation analysis with PROCESS (Hayes, 2013). We determined whether mediation exists by interpreting the indirect effect of extrinsic aspirations on brand loyalty and brand advocacy through BESC. Mediation analysis for intrinsic motivations was not performed, as no relationship was found between intrinsic motivations and BESC. Using the bootstrap sample distribution (the number of bootstrap samples for the percentile bootstrap confidence interval is 5,000), the upper and lower limits of the bootstrap confidence interval, as reported by PROCESS, are (.007 to .188) for loyalty $(\beta=.095)$ and $(.004$ to .173$)$ for advocacy $(\beta=.089)$. As the $95 \%$ confidence interval does not include 0 , we can infer significant mediation of extrinsic aspirations' effect on loyalty and advocacy through BESC at $\alpha=.05$. Next, the importance of the mediation was assessed by interpreting extrinsic aspirations' direct effect on loyalty and advocacy. The $p$-value of the direct effect on loyalty is .001, while the direct effect on advocacy is .004. Both effects are significant. Thus, we can conclude complementary partial mediation (Zhao, Lynch \& Chen, 2010).

\section{Conclusions}

This study contributed to the literature on BESC by developing and testing a comprehensive model aiming to explain the antecedents and consequences of BESC. The sample of respondents belonging to two cosplayer communities helped to provide further insights into the literature on fashion. Adopting the view that individuals use cosplayer clothes to express themselves and communicate either who they want to be or who they should be (Liu \& Hogg, 2018), the tendency to view a character as part of how they view themselves is mainly triggered by the strength of extrinsic aspirations. In other words, the higher is the individual's willingness to achieve financial success, gain social recognition and be appealing to others, the stronger is the propensity of the individuals to view characters as parts of themselves. As a consequence, these individuals show higher levels of loyalty and advocacy to their favourite characters.

Since the literature justifies the similarities to brands (e.g. Dotz, Morton $\&$ Lund, 1996), the same comprehensive model may reflect what happens between fashion brands and consumers. Thus, individuals' extrinsic aspirations increase their propensity to engage with fashion brands that in turn lead them to advocate and be loyal to their favourite brands. Moreover, mediation

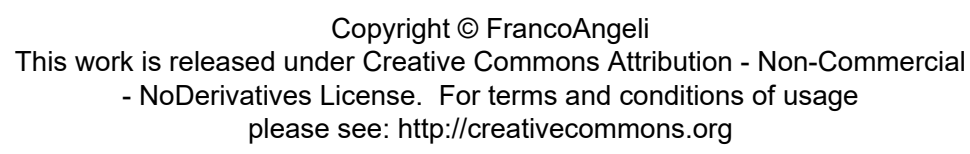


analysis (Hayes, 2013) revealed the indirect effect of extrinsic personal aspirations on brand loyalty and brand advocacy through BESC. Thus, this study confirmed the previous studies that attempt to provide a psychological explanation of brand loyalty and brand advocacy through the self-determination theory (e.g. Lin, Tsai \& Chiu, 2009). In this sense, BESC represents a psychological mechanism able to explain the effect of personal aspirations on brand loyalty and brand advocacy.

The peculiarity of the cosplayer community is useful to control the role of strong brand self-connection, maintaining its stability within the sample. As Sprott, Czellar and Spangenberg (2009) point out, measuring BESC on a large-scale basis might be impractical; consequently, firms are more likely to benefit from investigating specific target segments to adapt brand communication strategies according to their levels of BESC. Moreover, the cosplayer community is useful for investigating the role of brand engagement in the fashion industry. Indeed, as scholars show, fashion goods are usually used to express part of the self; thus, the concept of identification and the self-concept conveyed by a brand or a product is considerably relevant to the decision-making process of consumers. Consequently, the more a brand is able to convey its personality by exploring its own personification process (in some cases, with the help of a character), the higher the likelihood that consumers will choose that brand because they feel close (in terms of identity or personality) to it. As Razmus, Jaroszyńska and Palęga (2017) state, product brands convey to consumers certain meanings that, in the process of identification, may become part of their self-concept. In this sense, each brand can be represented by a collection of unique meanings generated in the course of marketing communications. Consequently, the tendency to include specific brands in one's self-concept can be highly varied in the context of building an appropriate image of the consumer. Moreover, brands need to enhance their capacity to be part of consumers' self-concept to be advocated and repurchased by them. Indeed, the consumer-brand connection relies both on the natural tendency of individuals to consider brands as part of their selfconcept and on the consumers' propensity to be loyal to specific brands. However, it also depends on the ability of brands to strengthen those associations and meanings that are relevant to consumers. Consequently, brands that are able to establish stronger connections with their customers (i.e. brands that gain higher levels of BESC and higher levels of loyalty) achieve a higher value than brands that are poorer in terms of relationships. Accordingly, managers should actively consider how to incorporate their brands into high-BESC consumers' self-concepts and how to inhibit other competing brands that threaten the existing relationship. Consequently, consumers' dif-

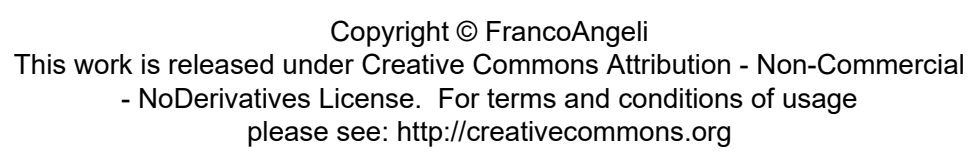


ferent natural tendencies (e.g. personal aspirations) must be considered, because they are able to determine different natural inclinations to engagement that lead to different propensities for brand loyalty and brand advocacy.

Given that this research does not consider moderators of the relationship between personal aspirations, BESC, brand loyalty and brand advocacy, future research should study other variables that affect this relationship (e.g., self-brand congruity). Another future development comes from the description of our sample that about $30 \%$ of the respondents are not loyal to a specific character, as they dress up as different characters at different events, rather than always dressing up as the same superhero. Accordingly, future studies could consider individuals' propensity to be loyal to brands as a possible moderator of the effect of personal aspirations on BESC. This could provide a relevant contribution to the literature on brand engagement in selfconcept, as the literature on the drivers and moderators of BESC is still lacking. 
Valentina Mazzoli, Diletta Acuti, Raffaele Donvito, Eunju Ko

\section{APPENDIX}

Table 2 - Construct items

\begin{tabular}{|c|c|}
\hline Variable & Items \\
\hline \multicolumn{2}{|l|}{$\begin{array}{l}\text { Intrinsic } \\
\text { aspirations }\end{array}$} \\
\hline \multirow[t]{3}{*}{ Self-acceptance } & $\begin{array}{l}\text { 1. At the end of my life, to be able to look back on it as meaningful and } \\
\text { complete. How important is this to you? }\end{array}$ \\
\hline & 2. To know and accept who I really am. How important is this to you? \\
\hline & $\begin{array}{l}\text { 3. To gain increasing insight into why I do the things I do. How important is this } \\
\text { to you? }\end{array}$ \\
\hline \multirow[t]{3}{*}{ Affiliation } & 1. To have good friends whom I can count on. How important is this to you? \\
\hline & 2. To share my life with someone I love. How important is this to you? \\
\hline & $\begin{array}{l}\text { 3. To feel that there are people who really love me and whom I love. How } \\
\text { important is this to you? }\end{array}$ \\
\hline \multirow[t]{3}{*}{ Community feeling } & $\begin{array}{l}\text { 1. To assist people who need help, asking nothing in return. How important is } \\
\text { this to you? }\end{array}$ \\
\hline & 2. To help others improve their lives. How important is this to you? \\
\hline & 3. To help people in need. How important is this to you? \\
\hline \multicolumn{2}{|l|}{$\begin{array}{l}\text { Extrinsic } \\
\text { aspirations }\end{array}$} \\
\hline \multirow[t]{3}{*}{ Financial success } & 1. To be personally wealthy. How important is this to you? \\
\hline & 2. To be financially successful. How important is this to you? \\
\hline & 3. To be rich. How important is this to you? \\
\hline \multirow{3}{*}{$\begin{array}{l}\text { Appealing } \\
\text { appearance }\end{array}$} & 1. To hide the signs of ageing successfully. How important is this to you? \\
\hline & $\begin{array}{l}\text { 2. To have people comment often about how attractive I look. How important is } \\
\text { this to you? }\end{array}$ \\
\hline & 3. To have an image that others find appealing. How important is this to you? \\
\hline \multirow[t]{3}{*}{ Social recognition } & $\begin{array}{l}\text { 1. To have a strong influence on others' beliefs and behaviour. How important } \\
\text { is this to you? }\end{array}$ \\
\hline & 2. To be appreciated and liked by many people. How important is this to you? \\
\hline & 3. To be popular. How important is this to you? \\
\hline \multirow[t]{8}{*}{$B E S C$} & 1. I have a special bond with the brands that I like. \\
\hline & 2. I consider my favourite brands to be a part of myself. \\
\hline & 3. I often feel a personal connection between my brands and me. \\
\hline & 4. Part of me is defined by important brands in my life. \\
\hline & 5. I feel as if I have a close personal connection with the brands I most prefer. \\
\hline & 6. I can identify with important brands in my life. \\
\hline & 7. There are links between the brands that I prefer and how I view myself. \\
\hline & 8. My favourite brands are an important indication of who I am. \\
\hline \multirow[t]{3}{*}{ Advocacy } & 1. I stick with the brand (character) I chose because I know it is the best for me. \\
\hline & 2. I will buy the brand (character) I chose the next time I buy. \\
\hline & 3. I intend to keep purchasing the brand (character) I chose. \\
\hline \multirow[t]{3}{*}{ Loyalty } & $\begin{array}{l}\text { 1. I will continue to use this brand (character) because I am satisfied and } \\
\text { acquainted with the brand. }\end{array}$ \\
\hline & 2. I will use this brand (character) in spite of competitors' deals. \\
\hline & 3. I prefer the brand (character) to others. \\
\hline
\end{tabular}




\section{References}

Aaker J., Fournier S., \& Brasel S. A. (2004). When good brands do bad. Journal of Consumer Research, 31(1): 1-16. DOI: 10.1086/383419.

Aggarwal P. (2004). The effects of brand relationship norms on consumer attitudes and behaviour. Journal of Consumer Research, 31(1): 87-101. DOI: $10.1086 / 383426$.

Aiken Jr L. R. (1963). The relationships of dress to selected measures of personality in undergraduate women. Journal of Social Psychology, 59(1): 119-128. DOI: 10.1080/00224545.1963.9919417.

ATA Blog. (2018). Who Are Today's Cosplay Makers? [Statistics and Demographics]. -- Retrieved from https://blog.anthonythomas.com/who-are-todays-cosplay-makers-statistics-and-demographics.

Belk R. W. (1988). Possessions and the extended self. Journal of Consumer Research, 15(2): 139-168. DOI: 10.1086/209154.

Berger J., \& Heath C. (2007). Where consumers diverge from others: identity signaling and product domains. Journal of Consumer Research, 34(2): 121-134.

Bovone L. (2006). Urban style cultures and urban cultural production in Milan: postmodern identity and the transformation of fashion. Poetics, 34(6): 370-382. DOI: 10.1016/j.poetic.2006.10.004.

Brodie R. J., Hollebeek L. D., Jurić B., \& Ilić A. (2011). Customer engagement: conceptual domain, fundamental propositions, and implications for research. Journal of Service Research, 14(3): 252-271.

Browne M. (1993). Alternative Ways of Assessing Model Fit. Testing Structural Equation Models, 136-162.

Bruner E. M. (1963). Encounters: two studies in the sociology of interaction. Erving Goffman. American Anthropologist, 65(6): 1416-1417.

Byrne B. M. (2016). Structural Equation Modeling with AMOS: Basic Concepts, Applications, and Programming. New York: Routledge.

Chaudhuri A., \& Holbrook M.B. (2001). The chain of effects from brand trust and brand affect to brand performance: the role of brand loyalty. Journal of Marketing, 65(2): 81-93.

Cox J., \& Dittmar H. (1995). The functions of clothes and clothing (dis) satisfaction: a gender analysis among British students. Journal of Consumer Policy, 18(2-3): 237-265. DOI: 10.1007/BF01016513.

Dessart L., Veloutsou C., \& Morgan-Thomas A. (2015). Consumer engagement in online brand communities: a social media perspective. Journal of Product \& Brand Management, 24(1): 28-42. DOI: 10.1108/JPBM-06-2014-0635.

Dotz W., Morton J., \& Lund J.W. (1996). What a Character. Hong Kong: World Studio.

Dwivedi A. (2015). A higher-order model of consumer brand engagement and its impact on loyalty intentions. Journal of Retailing and Consumer Services, 24: 100-109. DOI: 10.1016/j.jretconser.2015.02.007. 
Escalas J. E., \& Bettman J. R. (2003). You are what they eat: the influence of reference groups on consumers' connections to brands. Journal of Consumer Psychology, 13(3): 339-348.

Evans H. (2006). Fashions and feminine consumption. In: Latham K., Thompson S., \& Klein J. (editors). Consuming China: Approaches to Cultural Change in Contemporary China, pp. 173-189. Oxford: Routledge.

Ewing D. R., \& Allen C. T. (2017). Self-congruence is not everything for a brand: initial evidence supporting the relevance of identity cultivation in a college student role-identity context. Journal of Brand Management, 24(5): 405-422. DOI: 10.1057/s41262-017-0047-3.

Ferraro R., Escalas J.E., \& Bettman J. R. (2011). Our possessions, our selves: domains of self-worth and the possession-self link. Journal of Consumer Psychology, 21(2): 169-177.

Fetscherin M., \& Heinrich D. (2015). Consumer brand relationships research: a bibliometric citation meta-analysis. Journal of Business Research, 68(2): 380-390. DOI: 10.1016/j.jbusres.2014.06.010.

Flynn L.R., Goldsmith R.E., \& Korzenny F. (2011). Brand engagement in self-concept: a psychometric and demographic analysis. Journal of Multidisciplinary Research, 3(2): 5.

Geczy A. (2016). The psychology of cosplay. Journal of Asia-Pacific Pop Culture, 1(1): 18-36.

Grappi S., \& Visentin M. (2008). L'analisi delle determinanti dei comportamenti di fedeltà nel contesto retail: il ruolo dell'identificazione con il brand. Mercati e Competitività, 2: 1000-1015.

Han Y.J., Nunes J.C., \& Drèze X. (2010). Signaling status with luxury goods: the role of brand prominence. Journal of Marketing, 74(4): 15-30. DOI: 10.1509/jmkg.74.4.15.

Harmeling C. M., Moffett J. W., Arnold M. J., \& Carlson B. D. (2017). Toward a theory of customer engagement marketing. Journal of the Academy of Marketing Science, 45(3): 312-335.

Hassenzahl, M. (2018). The thing and I: understanding the relationship between user and product. Funology, 2: 301-313.

Hayes A. F. (2013). Introduction to Mediation, Moderation, and Conditional Process Analysis: A Regression-Based Approach. New York: Guilford Press.

Hendricks S. H., Kelley E. A., \& Eicher J.B. (1968). Senior girls' appearance and social acceptance. Journal of Home Economics, 60(3): 167-172. -- http://hdl. handle.net/11299/162564.

Hollebeek L. D. (2011). Demystifying customer brand engagement: exploring the loyalty nexus. Journal of Marketing Management, 27(7-8): 785-807.

Hollenbeck C. R., \& Kaikati A. M. (2012). Consumers' use of brands to reflect their actual and ideal selves on Facebook. International Journal of Research in Marketing, 29(4): 395-405. DOI: 10.1016/j.ijresmar.2012.06.002.

Holman R. H. (1980). Clothing as communication: an empirical investigation. In: Olson J. C. (ed.). NA-Advances in Consumer Research, Volume 07, Ann Abor, MI: Association for Consumer Research, pp. 372-377. 
Hosany S., Prayag G., Martin D., \& Lee W. Y. (2013). Theory and strategies of anthropomorphic brand characters from Peter Rabbit, Mickey Mouse, and Ronald McDonald, to Hello Kitty. Journal of Marketing Management, 29(1-2): 48-68. DOI: 10.1080/0267257X.2013.764346.

Hsiao C. H., Shen G. C. \& Chao P. J. (2015). How does brand misconduct affect the brand-customer relationship? Journal of Business Research, 68(4): 862-866. DOI: 10.1016/j.jbusres.2014.11.042.

Ito K., \& Crutcher P.A. (2014). Popular mass entertainment in Japan: manga, pachinko, and cosplay. Society, 51(1): 44-48. DOI: 10.1007/s12115-013-9737-y.

Jamal A., \& Goode M. M. (2001). Consumers and brands: a study of the impact of self-image congruence on brand preference and satisfaction. Marketing Intelligence \& Planning, 19(7): 482-492. DOI: 10.1108/02634500110408286.

Janssens W., De Pelsmacker P., Wijnen K., \& Van Kenhove P. (2008). Marketing Research with SPSS. New York: Pearson Education.

Kane L. L. E. (2017). Why cosplay? Motivations behind participation and use of social media among cosplayers who maintain Facebook artist pages. -- Retrievable at https://ir.library.oregonstate.edu/concern/graduate_thesis_or_dissertations/j098zd59k.

Kasser T., \& Ryan R. M. (1993). A dark side of the American dream: correlates of financial success as a central life aspiration. Journal of Personality and Social Psychology, 65(2): 410. DOI: 10.1037/0022-3514.65.2.410.

Kasser T., \& Ryan R. M. (1996). Further examining the American dream: differential correlates of intrinsic and extrinsic goals. Personality and Social Psychology Bulletin, 22(3): 280-287. DOI: 10.1177/0146167296223006.

Keller K. L. (1993). Conceptualizing, measuring, and managing customer-based brand equity. Journal of Marketing, 57: 1-22.

Kemp E., \& Bui M. (2011). Healthy brands: establishing brand credibility, commitment and connection among consumers. Journal of Consumer Marketing, 28(6): 429-437. DOI: $10.1108 / 07363761111165949$.

Kim C. K., Han D., \& Park S. B. (2001). The effect of brand personality and brand identification on brand loyalty: applying the theory of social identification. Japanese Journal of Psychological Research, 43(4): 195-206. DOI: 10.1111/ 1468-5884.00177.

Kim J., \& Kang J. Y. M. (2015). Investigation of the role of proximity of clothing to self anticipating risky appearance management behaviours. International Journal of Fashion Design, Technology and Education, 8(3): 235-242. DOI: 10.1080/ 17543266.2015.1074292.

Kim Y., Kasser T., \& Lee H. (2003). Self-concept, aspirations, and well-being in South Korea and the United States. Journal of Social Psychology, 143(3): 277290. DOI: 10.1080/00224540309598445.

Kumar V., Aksoy L., Donkers B., Venkatesan R., Wiesel T., \& Tillmanns S. (2010). Undervalued or overvalued customers: capturing total customer engagement value. Journal of Service Research, 13(3): 297-310. 
Leckie C., Nyadzayo M. W., \& Johnson L. W. (2016). Antecedents of consumer brand engagement and brand loyalty. Journal of Marketing Management, 32(56): 558-578. DOI: 10.1080/0267257X.2015.1131735.

Levy S. J. (1959). Symbols for sale. Harvard Business Review, 37: 117-124.

Likert R. (1932). A technique for the measurement of attitudes. Archives of Psychology, 22: 55 .

Lin C. P., Tsai Y. H., \& Chiu C. K. (2009). Modeling customer loyalty from an integrative perspective of self-determination theory and expectation-confirmation theory. Journal of Business and Psychology, 24(3): 315-326.

Liu C., \& Hogg M. K. (2018). Using attachment theory to understand consumers' tensions between their sense of self and goal-pursuits in relationships. Journal of Business Research, 92: 197-209. DOI: 10.1016/j.jbusres.2018.07.033.

Liu R. L., Sprott D. E., Spangenberg E. R., Czellar S., \& Voss K. E. (2018). Consumer preference for national vs. private brands: the influence of brand engagement and self-concept threat. Journal of Retailing and Consumer Services, 41: 90-100. DOI: 10.1016/j.jretconser. 2017.11.010.

Marketing Science Institute (2016). Research Priorities 2016-2018. Cambridge, MA: Marketing Science Institute. -- http//www.msi.org/uploads/files/ MSI_RP16-18.pdf.

Markus H. (1983). Self-knowledge: an expanded view. Journal of Personality, 51(3). DOI: 543-565.10.1111/j.1467-6494.1983.tb00344.x.

McCracken G. D., \& Roth V. J. (1989). Does clothing have a code? Empirical findings and theoretical implications in the study of clothing as a means of communication. International Journal of Research in Marketing, 6(1): 13-33. DOI: https://doi.org/10.1016/0167-8116(89)90044-X.

McNeill L. S. (2018). Fashion and women's self-concept: a typology for self-fashioning using clothing. Journal of Fashion Marketing and Management: An International Journal, 22(1): 82-98.

Muniz A. M., \& O'Guinn T. C. (2001). Brand community. Journal of Consumer Research, 27(4): 412-432. DOI: 10.1086/319618.

Niinimäki K. (2010). Eco-clothing, consumer identity and ideology. Sustainable Development, 18(3): 150-162. DOI: 10.1002/sd.455.

Oliver R. L. (1999). Whence consumer loyalty? Journal of Marketing, 63: 33. DOI: $10.2307 / 1252099$.

Otero-López J. M., \& Villardefrancos E. (2015). Compulsive buying and life aspirations: an analysis of intrinsic and extrinsic goals. Personality and Individual Differences, 76: 166-170. DOI: 10.1016/j.paid.2014.12.013.

Peirson-Smith A. (2013). Fashioning the fantastical self: an examination of the cosplay dress-up phenomenon in Southeast Asia. Fashion Theory, 17(1): 77-111. DOI: $10.2752 / 175174113 X 13502904240776$.

Peluchette J. V., Karl K., \& Rust K. (2006). Dressing to impress: beliefs and attitudes regarding workplace attire. Journal of Business and Psychology, 21(1): 45-63. 
Rahman O., Wing-Sun L., \& Cheung B. H. M. (2012). 'Cosplay': imaginative self and performing identity. Fashion Theory, 16(3): 317-341. DOI: 10.2752/ $175174112 X 13340749707204$.

Razmus W., Jaroszyńska M., \& Palęga M. (2017). Personal aspirations and brand engagement in self-concept. Personality and Individual Differences, 105: 294299. DOI: $10.1016 /$ j.paid.2016.10.018.

Robertson T. S. (1970). Consumer Behaviour. Glenview, IL: Scott-Foresman and Co.

Rosenberg R. S., \& Letamendi A. M. (2013). Expressions of fandom: findings from a psychological survey of cosplay and costume wear. Intensities: The Journal of Cult Media, 5: 9-18.

Rosenfeld L. B., \& Plax T. G. (1977). Clothing as communication. Journal of Communication, 27(2): 24-31. DOI: 10.1111/j.1460-2466.1977.tb01823.

Ryan R. M., \& Deci E. L. (2000). Self-determination theory and the facilitation of intrinsic motivation, social development, and well-being. American Psychologist, 55(1): 68. DOI: 10.1037/0003-066X.55.1.68.

Schmitt P., Skiera B., \& Van den Bulte C. (2011). Referral programs and customer value. Journal of Marketing, 75(1): 46-59.

Seregina A., \& Weijo H. A. (2016). Play at any cost: how cosplayers produce and sustain their ludic communal consumption experiences. Journal of Consumer Research, 44(1): 139-159. DOI: 10.1093/jcr/ucw077.

Sheldon K. M., Elliot A. J., Kim Y., \& Kasser T. (2001). What is satisfying about satisfying events? Testing 10 candidate psychological needs. Journal of Personality and Social Psychology, 80(2). DOI: 325.10.1037//O022-3514.80.2.325.

Sprott D., Czellar S., \& Spangenberg E. (2009). The importance of a general measure of brand engagement on market behaviour: development and validation of a scale. Journal of Marketing Research, 46(1): 92-104. DOI: 10.1509/ jmkr.46.1.92.

Stokburger-Sauer N., Ratneshwar S., \& Sen S. (2012). Drivers of consumer-brand identification. International Journal of Research in Marketing, 29(4): 406-418. DOI: 10.1016/j.ijresmar.2012.06.001.

Swaminathan V., Stilley K. M., \& Ahluwalia R. (2008). When brand personality matters: the moderating role of attachment styles. Journal of Consumer Research, 35(6): 985-1002.

Thompson C. J., \& Haytko D.L. (1997). Speaking of fashion: consumers' uses of fashion discourses and the appropriation of countervailing cultural meanings. Journal of Consumer Research, 24(1): 15-42. DOI: 10.1086/209491.

Thomson M., Whelan J., \& Johnson A. R. (2012). Why brands should fear fearful consumers: how attachment style predicts retaliation. Journal of Consumer Psychology, 22(2): 289-298. DOI: 10.1016/j.jcps.2011.04.006.

Torelli C. J., Monga A. B., \& Kaikati A. M. (2011). Doing poorly by doing good: corporate social responsibility and brand concepts. Journal of Consumer Research, 38(5): 948-963. 
Truong Y. (2010). Personal aspirations and the consumption of luxury goods. International Journal of Market Research, 52(5): 653-671. DOI: 10.2501/ S1470785310201521.

Truong Y., McColl R., \& Kitchen P. J. (2010). Uncovering the relationships between aspirations and luxury brand preference. Journal of Product \& Brand Management, 19(5): 346-355. DOI: 10.1108/10610421011068586.

Trusov M., Bucklin R. E., \& Pauwels K. (2009). Effects of word-of-mouth versus traditional marketing: findings from an internet social networking site. Journal of Marketing, 73(5): 90-102.

Van Doorn J., Lemon K. N., Mittal V., Nass S., Pick D., Pirner P., \& Verhoef P. C. (2010). Customer engagement behaviour: theoretical foundations and research directions. Journal of Service Research, 13(3): 253-266. DOI: 10.1177/ 1094670510375599.

Veblen T. (1899). The Theory of the Leisure Class: An Economic Study in the Evolution of Institutions. Oxford University Press.

Verlegh P. W., Ryu G., Tuk M. A., \& Feick L. (2013). Receiver responses to rewarded referrals: the motive inferences framework. Journal of the Academy of Marketing Science, 41(6): 669-682.

Vogel V., Evanschitzky H., \& Ramaseshan, B. (2008). Customer equity drivers and future sales. Journal of Marketing, 72(6): 98-108. DOI10.1509/jmkg.72.6.98.

Winge T. (2006). Costuming the imagination: origins of anime and manga cosplay. Mechademia, 1(1): 65-76. DOI: 10.1353/mec.0.0084.

Zhang S. S., van Doorn J., \& Leeflang P. S. H. (2014). Does the importance of value, brand and relationship equity for customer loyalty differ between Eastern and Western cultures? International Business Review, 23: 284-292. DOI: 10.1016/ j.ibusrev.2013.05.002.

Zhao X., Lynch J. G., \& Chen Q. (2010). Reconsidering Baron and Kenny: myths and truths about mediation analysis. Journal of Consumer Research, 37(2): 197206. 